\title{
Mechanical closure of the left atrial appendage: Is it time to be more aggressive?
}

\author{
James L. Cox, MD
}

Supplemental material is available online.

Atrial fibrillation (AF) is present in $1 \%$ to $2 \%$ of the general population, and its prevalence has been predicted to increase more than fivefold within the next 40 years. ${ }^{1,2}$ Patients with $\mathrm{AF}$ are at least five times more likely to have a stroke than patients without $\mathrm{AF}^{3}$ Approximately $90 \%$ of all strokes are ischemic, and $15 \%$ to $20 \%$ of all ischemic strokes are associated with $\mathrm{AF}^{4-6}$ The left atrial appendage (LAA) is the site of more than $90 \%$ of detected thrombi in patients with $\mathrm{AF}^{7}$ As a result of the recent development of potentially safer and more effective percutaneous devices ${ }^{8-10}$ and minimally invasive surgical techniques ${ }^{11,12}$ for closing the LAA, interest is renewed in the potential for using these mechanical approaches to decrease the incidence of stroke in patients with $\mathrm{AF}^{13,14}$

\section{EFFECT OF LAA CLOSURE ON THE INCIDENCE OF STROKE}

Previous studies designed to determine the effect of closure of the LAA on the incidence of stroke have yielded mixed results. ${ }^{15,16}$ One reason is that patients with $\mathrm{AF}$ frequently have associated comorbidities that could themselves be the source of ischemic strokes (eg, intracerebral vascular disease, carotid artery stenosis, atherosclerosis of the proximal aorta, valvular heart disease, and left heart failure).

The first large, prospective, randomized trial to evaluate the effect of LAA closure on the subsequent incidence of stroke was reported in 2005 and included patients undergoing coronary artery bypass grafting (CABG). ${ }^{15}$ The Left Atrial Appendage Occlusion Study included patients whose

\footnotetext{
From the Division of Cardiothoracic Surgery, Washington University School of Medicine, Barnes-Jewish Hospital, St Louis, Mo.

Disclosures: Dr Cox is a nonemployee consultant for the following companies: Adagio, Inc, Laguna Hills, Calif; Atricure, Inc, West Chester, Ohio; CorMatrix Cardiovascular, Inc, Roswell, Ga; Estech, Inc, San Ramon, Calif; SentreHEART, Inc, Palo Alto, Calif.

Received for publication July 3, 2013; accepted for publication July 9, 2013; available ahead of print Sept 3, 2013.

Address for reprints: James L. Cox, MD, 1600 Glenarm Place, No. 3002, Denver, CO (E-mail: jamescoxmd@aol.com).

J Thorac Cardiovasc Surg 2013;146:1018-27

$0022-5223 / \$ 36.00$

Copyright (c) 2013 by The American Association for Thoracic Surgery http://dx.doi.org/10.1016/j.jtcvs.2013.07.011
}

LAA was closed by 1 of 2 methods, epicardial suture or epicardial stapling. However, complete closure was attained with the suture technique in only $43 \%$ of patients, with the predominant failure mode a residual or recurrent connection between the LAA and the left atrium. Stapling was successful in only $72 \%$ of patients, and the other $28 \%$ were considered to have treatment failures because of a persistent remnant at the base of the LAA that was greater than $1 \mathrm{~cm}$ in length. Largely because of this inability to attain permanent LAA closure, the Left Atrial Appendage Occlusion Study did not show a significant reduction in the incidence of stroke between the study (occlusion) and control groups. Further complicating the question of whether closure of the LAA should be attempted was the observation that incomplete closure is often more dangerous than no closure at all. ${ }^{15,16}$

Despite the technical inadequacies and equivocal results of such surgical studies, the "American College of Cardiology/American Heart Association guidelines for the management of patients with valvular heart disease" recommend amputation of the LAA at mitral valve surgery to reduce the incidence of subsequent thromboembolic events. ${ }^{17}$ Moreover, the "American Heart Association/ American College of Cardiology/European Society of Cardiology guidelines for the management of patients with atrial fibrillation" have recommended surgical LAA closure in cardiac surgical patients "...who are at risk of developing postoperative AF." 7 These consensus recommendations for relatively small, highly selected, groups of patients are clearly based on recognition of the importance of the LAA in the genesis of strokes associated with AF. However, they beg the question of whether similar recommendations should be made to close the LAA in the millions of patients in the general population who have AF. Catheter ablation has been performed for AF for nearly 2 decades and, despite 2- to 5-year recurrence rates of more than $70 \%$ after a single catheter ablation, ${ }^{18-20}$ concomitant closure of the LAA is not a routine part of these procedures, largely because the new catheter-based closure devices were not yet approved by the Food and Drug Administration (FDA). In addition, many of the contemporary minimally invasive surgical procedures for AF also do not routinely include closure of the LAA. ${ }^{21}$

Our experience with the surgical treatment of $\mathrm{AF}$ suggests that removal or proper closure of the LAA at surgery reduces the risk of early perioperative strokes dramatically and nearly eliminates the risk of subsequent 


$$
\begin{aligned}
& \text { Abbreviations and Acronyms } \\
& \begin{aligned}
\text { AF } & =\text { atrial fibrillation } \\
\text { CABG } & =\text { coronary artery bypass grafting } \\
\text { FDA } & =\text { Food and Drug Administration } \\
\text { LA } & =\text { left atrial } \\
\text { LAA } & =\text { left atrial appendage } \\
\text { RA } & =\text { right atrial }
\end{aligned}
\end{aligned}
$$

long-term stroke. ${ }^{22}$ The incidence of perioperative stroke has been $3.2 \%$ after $\mathrm{CABG}, 2.8 \%$ after valve surgery, and $6.7 \%$ after CABG plus valve surgery. ${ }^{23}$ However, in our experience when a maze procedure for $\mathrm{AF}$ was performed either as a "stand-alone" procedure or was added to these other surgical operations as a "concomitant" procedure, the incidence of perioperative stroke decreased to less than $1 \% .^{24}$ This observation was particularly surprising because nearly $20 \%$ of the patients in our series had a history of at least 1 systemic thromboembolic event before their surgery, putting them at an even greater risk of perioperative stroke.

One might suspect that because of the concomitant maze procedure those patients did not have perioperative AF and, therefore, fewer perioperative strokes occurred for that reason. However, $37 \%$ of those patients had perioperative AF. Only patients with a history of previous stroke or transient ischemic attack and those with mechanical valve prostheses were anticoagulated with warfarin in the immediate postoperative period. The remaining patients, representing a substantial majority, received no early postoperative anticoagulation, although they were routinely instructed to take aspirin. Thus, the only plausible explanation for the dramatic reduction in the expected perioperative stroke rate in such high-risk patients was that the LAA was either removed or properly closed in every patient as a part of the maze procedure.

In the original "cut-and-sew" maze patients, the excised LAAs were immediately examined for thrombi at surgery by opening them longitudinally from the base to the tip. When the original "cut-and-sew" maze procedure was supplanted by the minimally invasive "cryosurgical maze procedure" in the mid-1990s, ${ }^{25}$ the LAA was no longer excised but instead was inverted into the left atrial cavity, directly examined for thrombi, returned to its normal position, and closed endocardially. This direct visual examination of the LAA in 360 patients, $19 \%$ of whom had previously experienced either a stroke or transient ischemic attack, revealed small thrombi in the trabeculated LAA in only 2 patients, both of whom had experienced multiple thromboembolic episodes within the week before undergoing an emergency maze procedure for the recurrent strokes. No thrombi were found elsewhere inside the left atrium, pulmonary veins, or left ventricle in any of the 360 patients.

During the 15 years after the maze procedure and surgical removal or endocardial suture closure of the LAA, only 1 patient experienced an ischemic stroke. ${ }^{26}$ Of those patients, $65 \%$ had received no long-term anticoagulation, and the only indication for long-term anticoagulation in the remaining $35 \%$ was the presence of a mechanical valve prosthesis, AF recurrence, or the preference of the referring physician. It has been suggested that the dramatic reduction in the expected long-term stroke rate in these high-risk patients was because $94 \%$ of them were still free of AF after 15 years. ${ }^{27}$ However, because of the dramatic decrease in the incidence of perioperative strokes in the same patients, a more plausible explanation is that the LAA had either been removed or properly closed in all the patients.

\section{PATHOPHYSIOLOGY OF LEFT HEART THROMBOSIS IN AF}

The 3 factors constituting "Virchow's triad" responsible for spontaneous intravascular thrombosis are hypercoagulability, endothelial injury, and stasis of blood flow. ${ }^{28}$ A recent study by Lim et $\mathrm{al}^{29}$ documented that $\mathrm{AF}$ itself, as well as prolonged rapid heart rates, can induce hypercoagulability that is more severe within the atria than in the peripheral circulation. Although their elegant study has provided an important insight into why patients with AF have an increased incidence of stroke, it did not explain why a difference exists between the incidence of right-heart and left-heart thromboembolism in patients with AF. Patients with hypercoagulation syndromes have the same hypercoagulability problem with blood inside the fibrillating right atrium as they do with blood inside the fibrillating left atrium. Thus, if hypercoagulability were the primary culprit in thromboembolism associated with AF, pulmonary embolism from the right heart should be as common as systemic embolism from the left heart.

The study by Lim et $\mathrm{al}^{29}$ also presented a case for AF-induced endothelial injury in both atria as a factor in promoting atrial thrombogenesis. Atrial stretching and fibrosis, with potential endothelial injury, would be expected to be more prominent in the left atrium than in the right atrium in patients with AF because many of them have left-sided heart problems such as hypertension, ischemic heart disease, and mitral and/or aortic valve disease. Thus, it is possible that a disparity in endothelial injury could be one reason thromboemboli originate more commonly in the left heart. However, this notion is only theoretical, because their study does not differentiate between endothelial injury in the right and left atria. In 


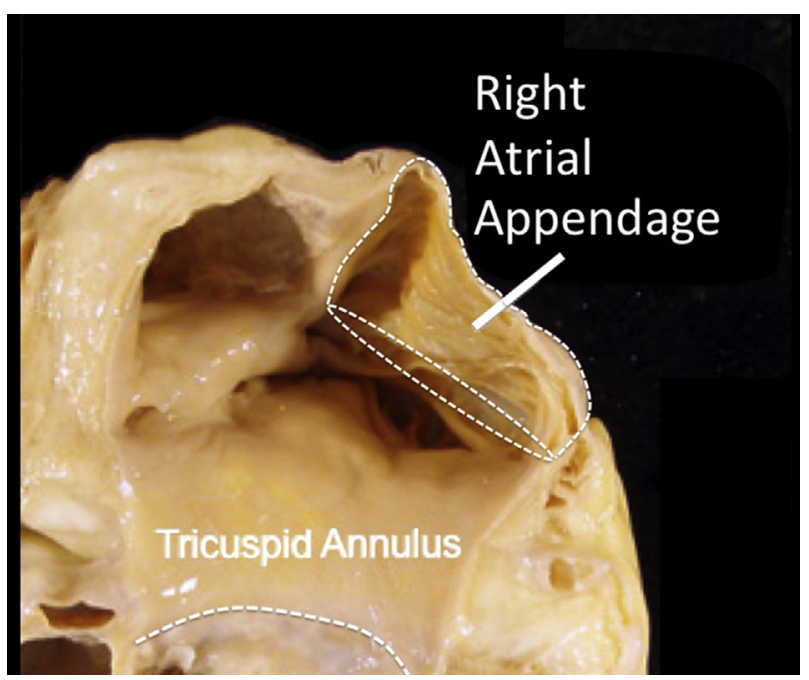

FIGURE 1. Anatomy of the right atrium showing the relatively large size of the orifice of the right atrial appendage in relation to its depth.

any event, differential right and left atrial endothelial injury is likely to be less important than the marked disparity in the degree of stasis in the right and left atria during AF.

Several reasons exist for the difference in right and left heart stasis during AF. Although both the right atrial (RA) appendage and LAA are heavily trabeculated in their distal portions, ${ }^{30}$ the orifice of the RA appendage is relatively broad in relation to its depth (Figure 1), and the wide orifice of the RA appendage is positioned adjacent to the predominant path of flow as blood courses from the superior and

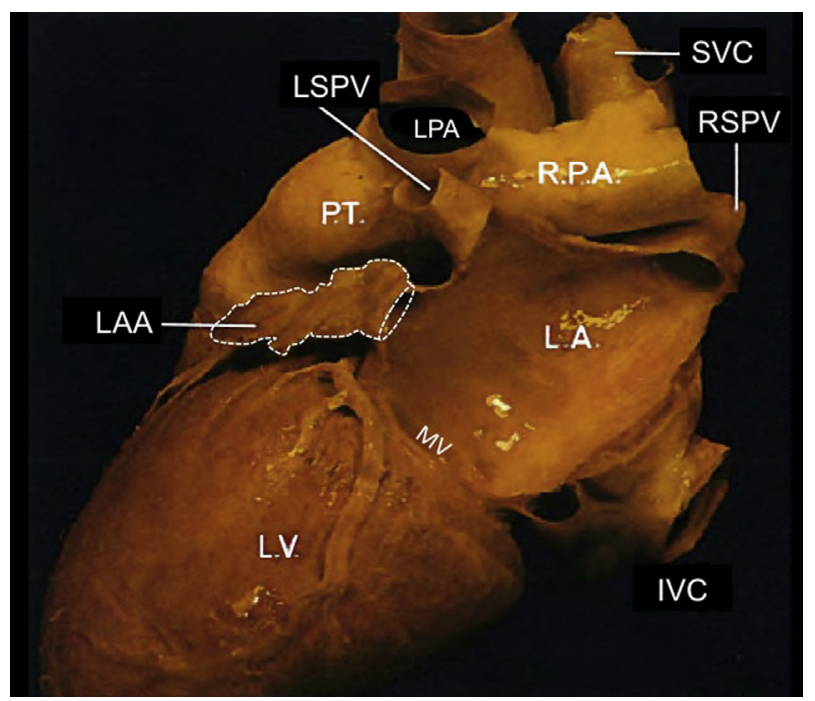

FIGURE 2. Anatomy of the left atrium showing the relatively small size of the orifice of the left atrial appendage ( $L A A)$ in relation to its depth. $L S P V$, Left superior pulmonary vein; $S V C$, superior vena cava; $L P A$, left pulmonary artery; $R S P V$, right superior pulmonary vein; $P T$, pulmonary trunk; $R P A$, right pulmonary artery; $L A$, left atrium; $M V$, mitral valve; $L V$, left ventricle; $I V C$, inferior vena cava. inferior vena cavae to the tricuspid valve. Thus, the interior of the RA appendage is continuously "washed" by the blood stream, even during AF. In contrast, the orifice of the LAA is quite small compared with its depth ${ }^{30}$ (Figure 2), and the blood from the nearby pulmonary veins flows more directly into the orifice of the mitral valve. Flow from the adjacent left pulmonary veins is actually directed away from the LAA orifice toward the mitral valve. Thus, the LAA, especially in its distal trabeculated portions, is not "washed" as thoroughly by the predominant blood stream during $\mathrm{AF}$ as is the RA appendage. Therefore, the degree of stasis in the LAA is substantially worse than that in the RA appendage at least in part because of differences in the anatomy.

The generally accepted notion of the pathophysiology of thromboembolism associated with $\mathrm{AF}$ is that a fixed thrombus forms in the left heart and then either the entire thrombus or a portion of it breaks off and embolizes systemically. ${ }^{31}$ However, our unique premortem observations of the inside of the LAA in the maze patients have suggested an alternative picture of the predominant pathophysiology of thromboembolism in AF. In this alternative scenario, severely static blood in the LAA congeals into a free-floating thrombus and, once formed, quickly embolizes to the systemic circulation, leaving no trace of its former, rather fleeting, existence. This view is most consistent with the absence of thrombi noted on premortem examination of the left heart and LAA in the vast majority of patients known to have had thromboembolic events associated with AF.

The specific site of thrombus formation within the LAA is important clinically, because it determines the level at which the appendage can be safely excluded. Some investigators have emphasized the necessity for closure or resection as near as possible to the anatomic "base" or "neck" of the LAA, suggesting that if a small pouch or diverticulum remains after closure, it might actually increase the likelihood of thrombus formation. ${ }^{15,32}$ However, virtually all LAAs are anatomically consistent in that the proximal 1 to $2 \mathrm{~cm}$ of the LAA is smooth and devoid of trabeculae. ${ }^{30} \mathrm{~A}$ small residual pouch of less than $1 \mathrm{~cm}$ at the base of a closed LAA using the newer closure devices has had no effect on the subsequent development of thromboembolism from that pouch remnant. ${ }^{10,15}$ Clearly, a much greater potential problem with contemporary closure devices is that some of them leave a residual connection between the body of the left atrium and the LAA itself.

\section{POTENTIAL CONSEQUENCES OF LAA CLOSURE OR REMOVAL}

\section{Arrhythmogenicity}

Recent studies have shown that the LAA can be the site of triggers that can induce episodes of paroxysmal AF and of 
re-entrant drivers that participate in the maintenance of persistent $\mathrm{AF}^{33,34}$ Therefore, exclusion of the LAA electrically can result in an improvement in the results of interventional catheter and surgical procedures for AF.

\section{LA Transport Function}

During sinus rhythm, the mechanical activity of a normal left atrium can be divided into 3 phases: a reservoir phase (expansion) during ventricular systole, a conduit phase during early ventricular diastole, and an active contractile phase during late ventricular diastole. ${ }^{35}$ Because transport function of the LAA itself can be differentiated from that of the left atrium, a theoretical possibility exists that loss of the LAA's contribution to 1 or more of these 3 phases could result in a decrease in forward cardiac output. ${ }^{36}$ However, this concern assumes that LA function equates to bi-atrial function, an assumption that is incorrect.

Atrioventricular synchrony is generally accepted to increase the cardiac output roughly $20 \%$ compared with the cardiac output during AF or ventricular pacing. However, this improvement in cardiac output occurs only when both atria are contracting in synchrony with their respective ventricles. In 1980, we described a procedure in which the entire left atrium, including the LAA, was surgically isolated, both electrically and mechanically, from the remainder of the heart. ${ }^{37}$ This so-called LA

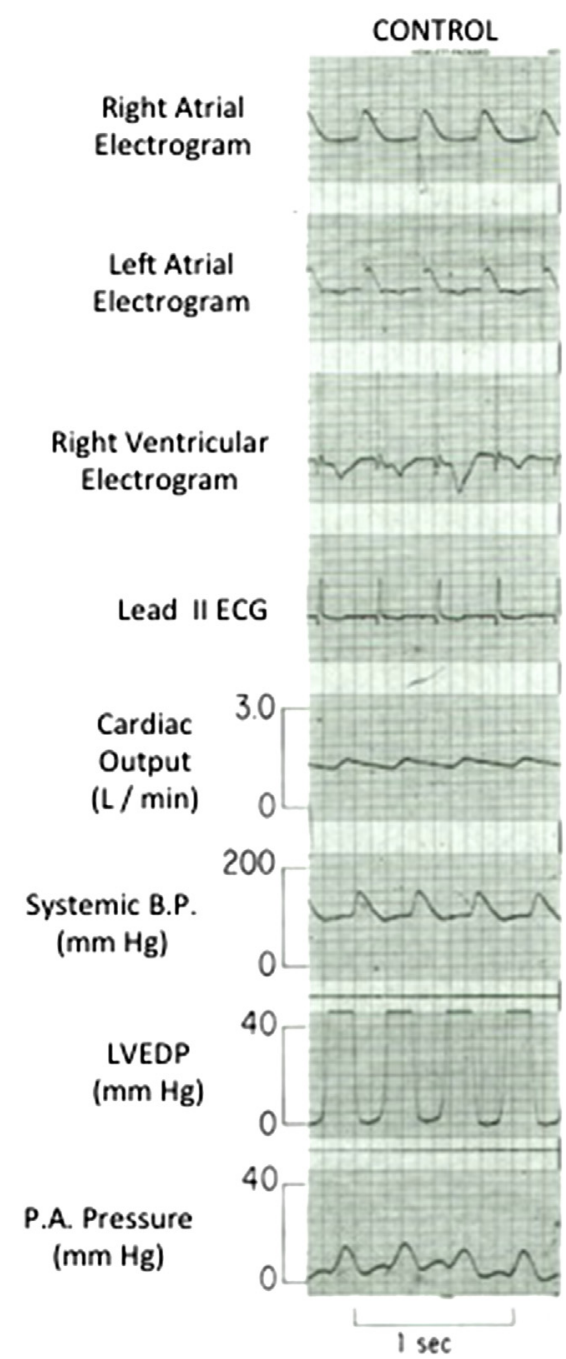

SILENT L.A.

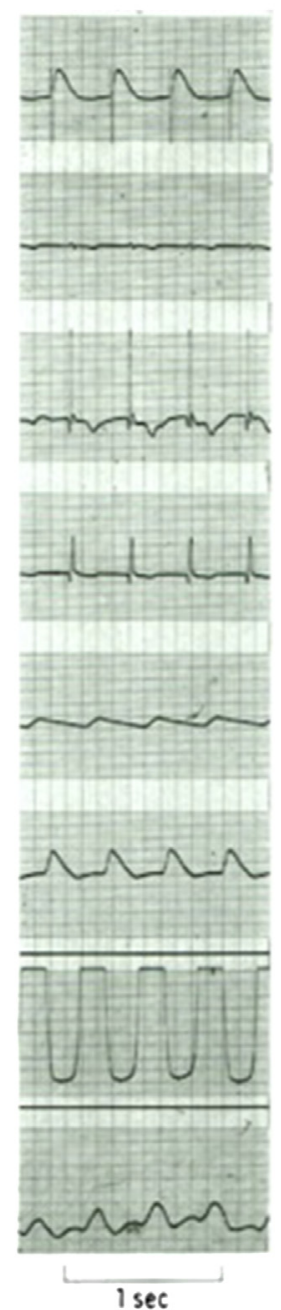

L.A. SVT

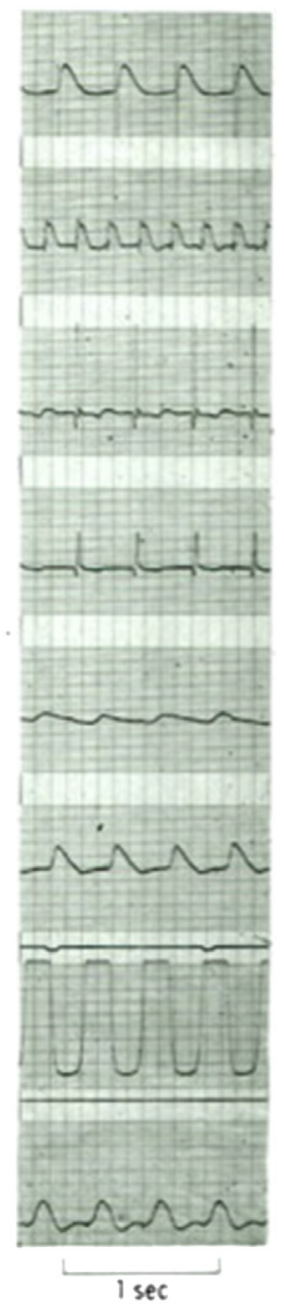

FIGURE 3. Postoperative electrograms of the right atrium, left atrium (L.A.), right ventricle, and lead II electrocardiogram are recorded during simultaneous monitoring of the cardiac output (aortic flow), systemic arterial blood pressure (B.P.), left ventricular end-diastolic pressure (LVEDP), and pulmonary artery (P.A.) pressure. In the control tracings, the right and left atria are both being paced, but the pacing stimulus to the left atrium is delayed $30 \mathrm{~ms}$ to simulate the exact activation pattern that existed preoperatively during normal sinus rhythm. The pacing stimulus to the left atrium is then abruptly discontinued (Silent L.A.). No alterations in normal atrioventricular conduction from the right atrium occur, yet there is no change in left ventricular preload, afterload, or cardiac output. The left atrium is then paced at a rate of $300 \mathrm{pulses} / \mathrm{min}$ (L.A. SVT), with no alteration in normal atrioventricular conduction from the right atrium or in the preload, afterload, or cardiac output. (Reproduced with permission from Williams et al. ${ }^{37}$ ) SVT, Supraventricular tachycardia; $E C G$, electrocardiogram. 
isolation procedure was developed before sophisticated intraoperative mapping techniques were available and was designed to confine automatic LA tachycardias to the left atrium, thereby freeing the sinoatrial node to drive the right atrium and both ventricles. Although this was strictly an antiarrhythmia operation, electromechanical isolation of the left atrium provided a unique opportunity to evaluate the contribution of LA contraction alone to forward cardiac output. Our experimental studies demonstrated that as long as synchronous activation is present of the right atrium and right ventricle, synchronous LA contraction has no effect on the preload, afterload, or forward cardiac output of the left ventricle (Figure 3). As long as the right heart is capable of delivering normal cardiac output through the pulmonary vasculature to the left atrium, the left ventricle will accept that output and deliver it to the systemic circulation, regardless of the status of LA function or that of its appendage. Because the mechanical activity of the entire left atrium, including the LAA, has no discernable independent effect on forward cardiac output, closure of only the LAA would likewise not have a significant independent effect on cardiac hemodynamics.

These observations emphasize that the importance of atrioventricular synchrony is the timing, not the force, of the atrial contraction in late ventricular diastole. A useful analogy is to think of a child on a backyard swing. If the adult swinging the child were to stop the child at the apogee of each swing cycle and then forcefully push the child every swing cycle, a great deal of energy would have to be expended to keep the child swinging. However, experience tells us that once the child is already swinging, only a light "tap" on the child's back at exactly the right time in the swing cycle will keep the child swinging indefinitely. The same dynamic principle is at work between the atria and their respective ventricles during atrioventricular synchrony, and it appears to be the primary mechanism that results in what we perceive as being a forceful atrial "contraction." During atrioventricular synchrony, the atrium provides a light "tap" to the already moving atrial blood pool at precisely the right time, thereby enhancing the efficiency of ventricular filling during ventricular diastole. Rather than using the term "atrial kick," perhaps it would be more accurate to refer to the participation of the atrium as an "atrial tap."

\section{Regulation of Fluid Balance}

The LAA has stretch receptors that can partially regulate thirst and other endocrine-like cells that help to regulate fluid balance by producing atrial natriuretic peptide. ${ }^{38}$ Removal of the LAA temporarily reduces the circulating levels of atrial natriuretic peptide, sometimes resulting in excessive fluid retention in the immediate postoperative period. This was a common early complication of the original cut-and-sew maze procedure in which both the LAA and RA appendage were excised. ${ }^{39}$ Subsequent iterations of the maze procedure retained the RA appendage, ${ }^{40}$ which also produces atrial natriuretic peptide $^{41}$ and, therefore, ameliorated this complication of LAA removal.

\section{CONTEMPORARY METHODS FOR CLOSING THE LAA \\ Surgical Techniques}

The previous difficulty in attaining complete appendage closure has largely been overcome by the recent introduction of external clips that can be positioned quickly and easily near the base of the LAA during surgery. The device most commonly used is the AtriClip (Atricure, Inc, West Chester, Ohio), which is designed so that the inherent expansive force exerted by the nitinol is directed centrally from both sides of the clip to apply a constant dynamic pressure to the base of the LAA, thereby keeping it closed permanently. ${ }^{12}$ This external clip not only closes the LAA effectively, but it also interrupts the myocardial

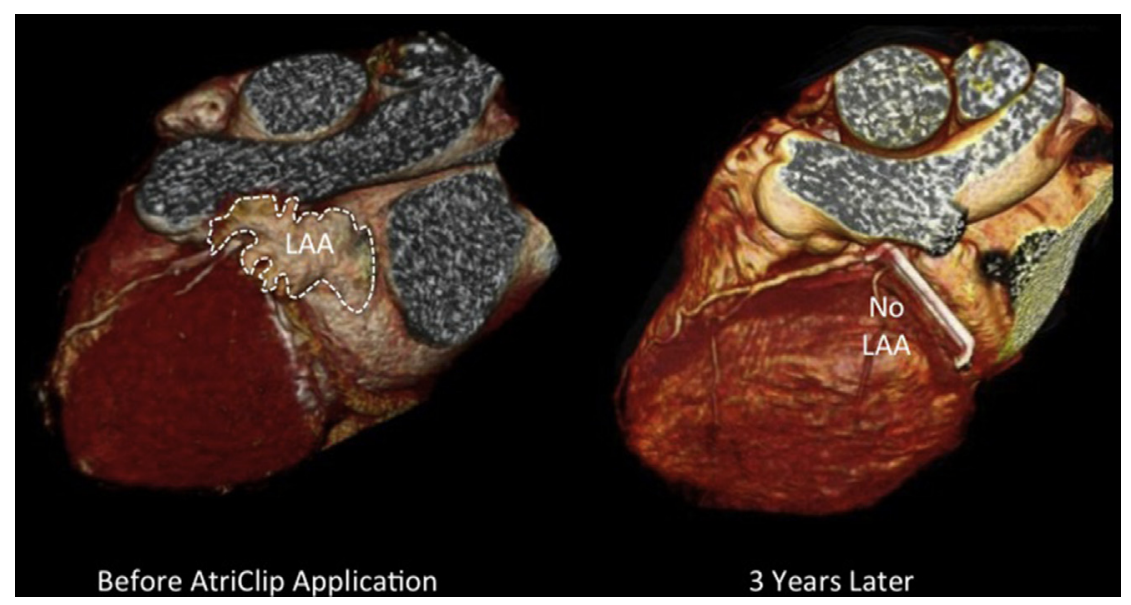

FIGURE 4. Disappearance of the left atrial appendage ( $L A A)$ after application of the external surgical AtriClip. (Modified from Ailawadi et al. ${ }^{12}$ ) 


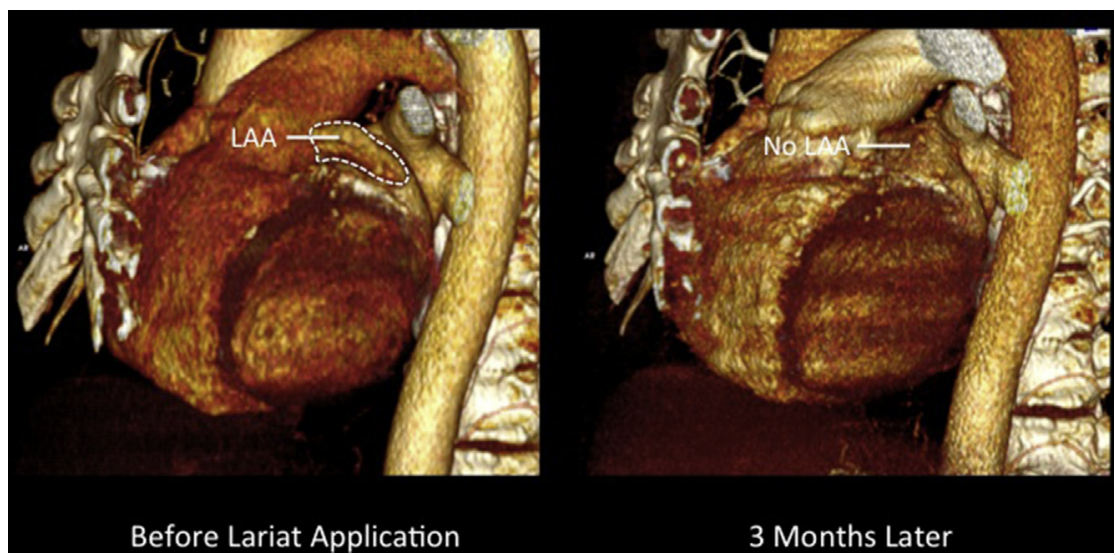

FIGURE 5. Disappearance of the left atrial appendage $(L A A)$ after application of the external percutaneous Lariat.

blood supply of the appendage itself, resulting in its gradual disappearance (Figure 4). In the multicenter FDA-approved Atricure Exclusion of the LAA in Patients Undergoing Concomitant Cardiac Surgery (EXCLUDE) trial, the LAA was closed successfully with the AtriClip device in $98.4 \%$ of patients, with no device-related mortality. ${ }^{12}$

\section{Percutaneous Nonsurgical Techniques}

The safety and efficacy of the Watchman device (Boston Scientific, Natick, Mass) for LAA occlusion were compared with those of standard oral anticoagulation therapy for the reduction of stroke in the Percutaneous Closure of the Left Atrial Appendage Versus Warfarin Therapy for Prevention of Stroke in Patients With Atrial Fibrillation (PROTECT-AF) trial. ${ }^{8,42}$ The latest follow-up data of that trial's 800 patients showed for the first time that the Watchman is superior to warfarin for the primary efficacy endpoint and equivalent to oral anticoagulation for the primary safety endpoint. ${ }^{43}$ The safety and efficacy of the Amplatzer plug (St Jude Medical Inc, St. Paul, Minn) for LA closure appear to be similar to those of the Watchman. ${ }^{9,44}$ However, both devices have the same major disadvantage in that a relatively large foreign body remains permanently inside the left atrium.

The Lariat system (SentreHEART Inc, Palo Alto, Calif) precludes the problem of a permanent intracardiac foreign body because the LAA is closed with a single ligature around the outside of the LAA. ${ }^{10}$ One disadvantage of the Lariat system is that it requires a "dry stick" of the pericardium for the introduction of the pericardial catheter, although this has not proved to be a significant deterrent to its use by nonsurgeons. The Lariat system also requires an endocardial catheter and incorporates magnets on both the endocardial balloon catheter and the pericardial catheter to accomplish optimal placement of the epicardial ligature near the base of the LAA. Because different operators are incapable of tightening a suture around the appendage with the same degree of pressure, the Lariat system includes the TenSURE tightening device, which always applies the same tightening pressure, thus eliminating individual operator variability. Soft tissue, such as the LAA, can remodel around the tightened ligature soon after placement. Therefore a 5-minute "waiting period" after the initial ligature tightening must be allowed before the ligature undergoes its final tightening with the TenSURE device. The Lariat system has 2 other features that offer advantages over the Watchman and Amplatzer devices: (1) the status of LAA closure can be monitored continuously and in real time by the operator during the procedure using echocardiography and/or angiography, and (2) the device can be released for better positioning during the procedure if necessary.

In the Permanent Ligation Approximation Closure Exclusion (PLACE) II study of the Lariat system, imaging techniques were used to evaluate the status of the LAA before and during the procedure and at 30 days, 90 days, and 1 year after the procedure. ${ }^{10}$ Despite a more rigid definition of "successful closure" than was used for the Watchman, the Lariat system attained complete closure by transesophageal echocardiography at 1 and 3 months after ligation. Of the patients undergoing transesophageal echocardiography 1 year later, $98 \%$ had complete closure of the LAA, including the patients with previous leaks at 1 and/or 3 months. Just as with the surgical AtriClip, the catheter-based Lariat system, with its epicardial ligature, interrupts the myocardial blood supply of the LAA, resulting in its gradual disappearance over time (Figure 5).

\section{PATIENTS WHO SHOULD BE CONSIDERED FOR MECHANICAL LAA CLOSURE}

Because the Watchman device has now been shown to be superior in efficacy and equivalent in safety to oral anticoagulation, it is reasonable to assume that the Amplatzer plug, with a similar risk/benefit profile, would offer similar results compared with oral anticoagulation, although that has not yet been proved. The early 
performances of the Watchman, Amplatzer plug, and Lariat systems suggest that interventional cardiologists might soon be able to close the LAA with an approved percutaneous device that is safer and more effective than oral anticoagulant therapy for the prevention of strokes. Should that potential be realized, not only with the percutaneous devices, but also with the surgical AtriClip, the most pressing issue would be to identify those patients who might benefit most from mechanical closure of the LAA as prophylaxis for ischemic strokes.

\section{Patients With AF Who Cannot Take Anticoagulants}

Clearly, patients with AF who cannot take anticoagulants should be considered for mechanical closure of the LAA. The demonstration of superiority of the Watchman device compared with oral anticoagulation therapy also raises the question of whether mechanical closure of the LAA should be considered even for patients who can take oral anticoagulation. Although oral anticoagulation clearly decreases the incidence of ischemic strokes in patients with $\mathrm{AF}^{45,46}$ unlike the mechanical devices, it also increases the incidence of hemorrhagic strokes, which are more lethal than ischemic strokes. ${ }^{47,48}$ Moreover, a major problem with oral anticoagulation therapy is that only about one half of all patients who are candidates for oral anticoagulant therapy are actually anticoagulated adequately, either because of difficulties in maintaining patients within the therapeutic international normalized ratio range or patient noncompliance. ${ }^{49,50}$ This observation suggests that any patient considered for oral anticoagulation should also be considered for mechanical closure of the LAA. Exceptions would include only those patients who will be strictly compliant with oral warfarin therapy and who can be maintained reliably within the therapeutic international normalized ratio range. An important development that could modify this more aggressive approach to mechanical closure is the recent introduction of newer anticoagulants such as dabigatran, rivaroxaban, and apixaban, all of which have shown noninferiority or superiority to warfarin in preventing ischemic stroke. ${ }^{51}$ These new agents require no therapeutic drug monitoring; however, patient adherence, lack of a reversal agent, cost, and other safety concerns remain reasons for caution. Furthermore, older adults have experienced more adverse effects from these agents.

\section{Patients Undergoing Catheter Ablation for AF}

Electrophysiologists performing catheter ablation for $\mathrm{AF}$ have rarely used these LAA occluding devices, primarily because of current FDA restrictions. However, the promising risk/benefit ratio of the percutaneous catheter-based systems should offer interventional electrophysiologists the future option of closing the LAA in patients undergoing catheter ablation for AF. Moreover, LAA closure might improve catheter ablation outcomes, such as was suggested by the recent demonstration that LAA ligation appears to decrease the AF burden. ${ }^{33,34,52}$ Because the percutaneous LARIAT system and surgical AtriClip are the only mechanical devices that are capable of causing complete electromechanical isolation of the myocardium of the LAA by devascularization, they would seem to be the ones most likely to improve catheter ablation outcomes for AF.

\section{Patients With AF Not Considered Candidates for Interventional Therapy}

Patients with AF who are not candidates for either catheter ablation or surgery represent the largest group at risk of stroke due to $\mathrm{AF}$, numbering in the millions in the United States alone. The best estimates from industry sources have suggested that some 311,000 patients underwent catheter ablation for AF in 2012, representing only $2.1 \%$ of all patients with $\mathrm{AF}^{53}$ Many, if not most, of these patients have nonparoxysmal (persistent or long-standing persistent) $\mathrm{AF}$ and are not considered good candidates for catheter ablation, and other patients have too many comorbidities or are too infirm to be candidates for hours-long catheter ablation procedures or invasive surgical procedures. One future option for these patients is to ablate the His bundle, insert a permanent pacemaker, and close the LAA, all of which would be attainable without surgery. ${ }^{54}$ In patients resistant to drug therapy and not candidates for interventional therapy, this "ablate, pace, and occlude" approach might prove the best option, even though it leaves the patients in $\mathrm{AF}$ and requires a permanent pacemaker. In such patients, it is prudent to remember that $\mathrm{AF}$ itself rarely kills patients, it is the strokes due to $\mathrm{AF}$ that kill patients.

\section{Patients Undergoing Cardiac Surgery With a History of $\mathbf{A F}$}

The vast majority of adult cardiac surgery falls into 3 categories: $\mathrm{CABG}$, aortic valve surgery, and mitral valve surgery. It is impossible to determine exactly how many of these patients enter the operating room annually in the United States with concomitant AF, but estimates have ranged from 60,000 to $100,000 .^{55,56}$ Using a median number of 80,000 patients, no more than 25,000 of them currently undergo a concomitant procedure for their $\mathrm{AF}$, with a success rate of approximately $80 \% .^{57,58}$ Ignoring $\mathrm{AF}$ in more than two thirds of these patients is difficult to justify knowing that the benefits of ablating AF with a concomitant AF surgical procedure include an improved quality of life, ${ }^{59}$ less perioperative morbidity, ${ }^{60}$ a lower incidence of perioperative thromboembolic events and valve morbidity, ${ }^{61,62}$ less tricuspid insufficiency, ${ }^{63,64}$ and improved long-term survival. ${ }^{62,65,66}$ At the 2010 Annual Meeting of the American Association for Thoracic 
Surgery, an independent survey of the attendees was conducted by questionnaire to determine the reasons $\mathrm{AF}$ is ignored by surgeons in more than two thirds of patients with concomitant $\mathrm{AF}$ (unpublished data). The overwhelming reason given was that surgeons were concerned about increasing the operative risk by adding additional surgery for AF to the primary coronary, aortic, or mitral procedure. Ad et $\mathrm{al}^{67}$ subsequently reported that adding the maze-III procedure to CABG and aortic valve surgery did not increase the morbidity or mortality of the procedures. In fact, their results suggested that the patients who had their AF addressed with concomitant surgery actually did better than those in whom the AF was ignored. ${ }^{67}$ Despite these studies documenting the safety and efficacy of treating both the primary cardiac problem and the concomitant $\mathrm{AF}$, if inexperienced surgeons continue to be reluctant to treat the concomitant AF, they should at least be willing to add a simple 5-minute procedure to close the LAA.

\section{All Patients Undergoing Cardiac Surgery}

Perioperative $\mathrm{AF}$ increases the risk of perioperative stroke, prolongs hospitalization and intensive care unit stays, and increases the 30-day operative mortality after cardiac surgery. ${ }^{68,69}$ The American Heart Association/ American College of Cardiology/European Society of Cardiology consensus recommendation for closure of the LAA in cardiac surgical patients at high risk of developing perioperative $\mathrm{AF}$ is complicated by the fact that approximately two thirds of all patients undergoing cardiac surgery will not develop perioperative AF, regardless of the procedure performed, ${ }^{70}$ and it is impossible to identify the remaining one third preoperatively. Thus, this consensus recommendation is not particularly helpful to the practicing cardiac surgeon. Because epicardial suture closure of the LAA by surgeons is fraught with both short- and long-term failure, and because of the current safety and efficacy of closing the LAA with an external clip, why not close the LAA in all patients undergoing cardiac surgery? Clearly, the greatest deterrent to such a suggestion is the added cost of the LAA clips. However, the cost of these devices is miniscule compared with the added costs attendant to perioperative strokes. $68,69,71$

\section{Patients With Subclinical AF}

All these patients had a clinical diagnosis of AF, except those in the last group and, therefore, are known to be at a fivefold risk of having an ischemic stroke. A recent study addressed patients with subclinical AF (tachyarrhythmias $>190$ beats/min for $>6$ minutes) discovered by previously implanted pacemakers or defibrillators with monitoring capabilities. $^{72}$ The study included 2580 patients aged 65 years or older with hypertension and no history of AF who were followed up for a mean of 2.5 years. The risk of stroke or systemic embolism associated with subclinical $\mathrm{AF}$ was $13 \%$. This ominous, but important, study raises the question of whether such high-risk patients should receive prophylactic oral anticoagulation therapy or mechanical LAA closure, despite having no history of AF.

\section{CONCLUSIONS}

The most debilitating and life-threatening complication of $\mathrm{AF}$ is stroke. Most strokes due to $\mathrm{AF}$ have their origin in the trabeculated portions of the LA appendage. Oral anticoagulation therapy for the prophylaxis of strokes associated with AF has been less than optimal and difficult to manage clinically. Several safe and effective percutaneous and surgical methods for closing the LAA have now been developed and will hopefully be fully approved by the FDA in the near future. These new devices and techniques have the capability of drastically reducing the number of strokes associated with AF. The LAA has been accurately termed "our most lethal human attachment,",73 and we are now obliged to consider its mechanical closure in a larger spectrum of the population. Routine mechanical closure of the LAA in a wider number and variety of patients would likely have a greater effect on the morbidity and mortality of the general population than any other single therapy for any other clinical problem within our grasp today. It is time for us to act on that potential without further delay.

\section{References}

1. Wilke T, Groth A, Mueller S, Pfannkuche M, Verheyen F, Linder R, et al Incidence and prevalence of atrial fibrillation: an analysis based on 8.3 million patients. Europace. 2013;15:486-93.

2. Naccarelli GV, Varker H, Lin J, Schulman KL. Increasing prevalence of atrial fibrillation and flutter in the United States. Am J Cardiol. 2009;104:1534-9.

3. Wolf PA, Abbott RD, Kannel WB. Atrial fibrillation as an independent risk factor for stroke: the Framingham Study. Stroke. 1991;22:983-8.

4. Lloyd-Jones D, Adams RJ, Brown TM, Carnethon M, Dai S, De Simone G, et al. Heart disease and stroke statistics-2010 update: a report from the American Heart Association. Circulation. 2010;121:e46-215.

5. Roger VL, Go AS, Lloyd-Jones DM, Adams RJ, Berry JD, Brown TM, et al. Heart disease and stroke statistics-2011 update: a report from the American Heart Association. Circulation. 2011;123:e18-209.

6. Saxena R, Lewis S, Berge E, Sandercock PA, Koudstaal PJ. Risk of early death and recurrent stroke and effect of heparin in 3169 patients with acute ischemic stroke and atrial fibrillation in the International Stroke Trial. Stroke. 2001;32: 2333-7.

7. Fuster V, Ryden LE, Cannom DS, Crijns HJ, Curtis AB, Ellenbogen KA, et al ACC/AHA/ESC 2006 guidelines for the management of patients with atrial fibrillation. Circulation. 2006;114:e257-354.

8. Holmes DR, Reddy VY, Turi ZG, Doshi SK, Sievert H, Buchbinder M, et al. Percutaneous closure of the left atrial appendage versus warfarin therapy for prevention of stroke in patients with atrial fibrillation: a randomised non-inferiority trial. Lancet. 2009;374:534-42.

9. Park JW, Bethencourt A, Sievert H, Santoro G, Meier B, Walsh K, et al. Left atrial appendage closure with Amplatzer cardiac plug in atrial fibrillation: initial European experience. Catheter Cardiovasc Interv. 2011;77:700-6.

10. Bartus K, Han FT, Bednarek J, Myc J, Kapelak B, Sadowski J, et al. Percutaneous left atrial appendage suture ligation using the LARIAT device in patients with atrial fibrillation: initial clinical experience. J Am Coll Cardiol. 2013;62:108-18.

11. DiSesa VJ, Tam S, Cohn LH. Ligation of the left atrial appendage using an automatic surgical stapler. Ann Thorac Surg. 1988;46:652-3. 
12. Ailawadi G, Gerdisch MW, Harvey RL, Hooker RL, Damiano RJJ, Salamon T, et al. Exclusion of the left atrial appendage with a novel device: early results of a multicenter trial. J Thorac Cardiovasc Surg. 2011;142:1002-9.

13. Contractor T, Khasnis A. Left atrial appendage closure in atrial fibrillation: a world without anticoagulation? Cardiol Res Pract. 2011;2011:752808.

14. Gangireddy SR, Halperin JL, Fuster V, Reddy VY. Percutaneous left atrial appendage closure for stroke prevention in patients with atrial fibrillation: an assessment of net clinical benefit. Eur Heart J. 2012;33:2700-8.

15. Healey JS, Crystal E, Lamy A, Teoh K, Semelhago L, Hohnloser SH, et al. Left Atrial Appendage Occlusion Study (LAAOS): results of a randomized controlled pilot study of left atrial appendage occlusion during coronary bypass surgery in patients at risk for stroke. Am Heart J. 2005;150:288-93.

16. Katz ES, Tsiamtsiouris T, Applebaum RM, Schwartzbard A, Tunick PA, Kronzon I. Surgical left atrial appendage ligation is frequently incomplete: a transesophageal echocardiographic study. J Am Coll Cardiol. 2000;36:468-71.

17. Bonow RO, Carabello BA, Chatterjee K, de Leon ACJ, Faxon DP, Freed MD, et al. 2008 Focused update incorporated into the ACC/AHA 2006 guidelines for the management of patients with valvular heart disease: a report of the American College of Cardiology/American Heart Association Task Force on Practice Guidelines (Writing Committee to Revise the 1998 Guidelines for the Management of Patients With Valvular Heart Disease): endorsed by the Society of Cardiovascular Anesthesiologists, Society for Cardiovascular Angiography and Interventions, and Society of Thoracic Surgeons. Circulation. 2008;118: e523-661.

18. Cheema A, Vasamreddy CR, Dalal D, Marine JE, Dong J, Henrikson CA, et al. Long-term single procedure efficacy of catheter ablation of atrial fibrillation. J Interv Card Electrophysiol. 2006;15:145-55.

19. Weerasooriya R, Khairy P, Litalien J, Macle L, Hocini M, Sacher F, et al. Catheter ablation for atrial fibrillation: are results maintained at 5 years of follow-up? J Am Coll Cardiol. 2011;57:160-6.

20. Tilz RR, Rillig A, Thum AM, Arya A, Wohlmuth P, Metzner A, et al. Catheter ablation of long-standing persistent atrial fibrillation: 5-year outcomes of the Hamburg sequential ablation strategy. J Am Coll Cardiol. 2012;60:1921-9.

21. Muneretto C, Bisleri G, Bontempi L, Curnis A. Durable staged hybrid ablation with thoracoscopic and percutaneous approach for treatment of long-standing atrial fibrillation: a 30-month assessment with continuous monitoring. $J$ Thorac Cardiovasc Surg. 2012;144:1460-5; discussion 1465.

22. Cox JL, Ad N, Palazzo T. Impact of the maze procedure on the stroke rate in patients with atrial fibrillation. J Thorac Cardiovasc Surg. 1999;118:833-40.

23. Salazar JD, Wityk RJ, Grega MA, Borowicz LM, Doty JR, Petrofski JA, et al. Stroke after cardiac surgery: short- and long-term outcomes. Ann Thorac Surg. 2001;72:1195-201; discussion 1201-2.

24. Cox JL, Schuessler RB, Lappas DG, Boineau JP. An 8 1/2-year clinical experience with surgery for atrial fibrillation. Ann Surg. 1996;224:267-73; discussion 273-5.

25. Cox JL. The minimally invasive maze-III procedure. Oper Tech Thorac Cardiovasc Surg. 2000;5:79-92.

26. Prasad SM, Maniar HS, Camillo CJ, Schuessler RB, Boineau JP, Sundt TM, et al. The Cox maze III procedure for atrial fibrillation: long-term efficacy in patients undergoing lone versus concomitant procedures. J Thorac Cardiovasc Surg. 2003;126:1822-8.

27. Chatterjee S, Alexander JC, Pearson PJ, Feldman T. Left atrial appendage occlusion: lessons learned from surgical and transcatheter experiences. Ann Thorac Surg. 2011;92:2283-92.

28. Lowe GD. Virchow's triad revisited: abnormal flow. Pathophysiol Haemost Thromb. 2003;33:455-7.

29. Lim HS, Willoughby SR, Schultz C, Gan C, Alasady M, Lau DH, et al. Effect of atrial fibrillation on atrial thrombogenesis in humans: impact of rate and rhythm. J Am Coll Cardiol. 2013;61:852-60.

30. Veinot JP, Harrity PJ, Gentile F, Khandheria BK, Bailey KR, Eickholt JT, et al. Anatomy of the normal left atrial appendage: a quantitative study of age-related changes in 500 autopsy hearts: implications for echocardiographic examination. Circulation. 1997;96:3112-5.

31. Black IW, Chesterman CN, Hopkins AP, Lee LC, Chong BH, Walsh WF. Hematologic correlates of left atrial spontaneous echo contrast and thromboembolism in nonvalvular atrial fibrillation. J Am Coll Cardiol. 1993;21:451-7.

32. Viles-Gonzalez JF, Kar S, Douglas P, Dukkipati S, Feldman T, Horton R, et al. The clinical impact of incomplete left atrial appendage closure with the Watchman device in patients with atrial fibrillation: a PROTECT AF (Percutaneous Closure of the Left Atrial Appendage Versus Warfarin
Therapy for Prevention of Stroke in Patients With Atrial Fibrillation) substudy. J Am Coll Cardiol. 2012;59:923-9.

33. Takahashi Y, Sanders P, Rotter M, Haissaguerre M. Disconnection of the left atrial appendage for elimination of foci maintaining atrial fibrillation. J Cardiovasc Electrophysiol. 2005;16:917-9.

34. Hocini M, Shah AJ, Nault I, Sanders P, Wright M, Narayan SM, et al. Localized reentry within the left atrial appendage: arrhythmogenic role in patients undergoing ablation of persistent atrial fibrillation. Heart Rhythm. 2011;8: 1853-61.

35. Stefanadis C, Dernellis J, Toutouzas P. A clinical appraisal of left atrial function. Eur Heart J. 2001;22:22-36.

36. Yamanaka K, Sekine Y, Nonaka M, Iwakura A, Yoshitani K, Nakagawa Y, et al. Left atrial appendage contributes to left atrial booster function after the maze procedure: quantitative assessment with multidetector computed tomography. Eur J Cardiothorac Surg. 2010;38:361-5.

37. Williams JM, Ungerleider RM, Lofland GK, Cox JL. Left atrial isolation: new technique for the treatment of supraventricular arrhythmias. J Thorac Cardiovasc Surg. 1980;80:373-80.

38. Potter LR, Yoder AR, Flora DR, Antos LK, Dickey DM. Natriuretic peptides: their structures, receptors, physiologic functions and therapeutic applications. Handb Exp Pharmacol. 2009;191:341-66.

39. Cox JL, Boineau JP, Schuessler RB, Kater KM, Lappas DG. Five-year experience with the maze procedure for atrial fibrillation. Ann Thorac Surg. 1993;56:814-23; discussion 823-4

40. Cox JL, Jaquiss RD, Schuessler RB, Boineau JP. Modification of the maze procedure for atrial flutter and atrial fibrillation. II. Surgical technique of the maze III procedure. J Thorac Cardiovasc Surg. 1995;110:485-95.

41. Omari BO, Nelson RJ, Robertson JM. Effect of right atrial appendectomy on the release of atrial natriuretic hormone. J Thorac Cardiovasc Surg. 1991;102:272-9.

42. Reddy VY, Doshi SK, Sievert H, Buchbinder M, Neuzil P, Huber K, et al. Percutaneous left atrial appendage closure for stroke prophylaxis in patients with atrial fibrillation: 2.3-year follow-up of the PROTECT AF (Watchman Left Atrial Appendage System for Embolic Protection in Patients with Atrial Fibrillation) trial. Circulation. 2013;127:720-9.

43. Reddy V, Doshi S, Sievert H, Buchbinder M, Neuzil P, et al. Long term results of PROTECT AF: the mortality effects of left atrial appendage closure versus warfarin for stroke prophylaxis in AF. Presented at the 2013 Annual Meeting of the Heart Rhythm Society, Denver, CO, May 9, 2013.

44. Danna P, Proietti R, Sagone A, Arensi A, Viecca M, Rago A, et al. Does left atrial appendage closure with a cardiac plug system reduce the stroke risk in nonvalvular atrial fibrillation patients? A single-center case series. Pacing Clin Electrophysiol. 2013;36:347-53.

45. The Boston Area Anticoagulation Trial for Atrial Fibrillation Investigators. The effect of low-dose warfarin on the risk of stroke in patients with nonrheumatic atrial fibrillation. N Engl J Med. 1990;323:1505-11.

46. Stroke Prevention in Atrial Fibrillation Investigators. Stroke prevention in atrial fibrillation study: final results. Circulation. 1991;84:527-39.

47. Cervera A, Amaro S, Chamorro A. Oral anticoagulant-associated intracerebral hemorrhage. J Neurol. 2012;259:212-24.

48. Sinnaeve PR, Brueckmann M, Clemens A, Oldgren J, Eikelboom J, Healey JS Stroke prevention in elderly patients with atrial fibrillation: challenges for anticoagulation. J Intern Med. 2012;271:15-24.

49. Gage BF, Boechler M, Doggette AL, Fortune G, Flaker GC, Rich MW, et al. Adverse outcomes and predictors of underuse of antithrombotic therapy in Medicare beneficiaries with chronic atrial fibrillation. Stroke. 2000;31:822-7.

50. Gallagher AM, Rietbrock S, Plumb J, van Staa TP. Initiation and persistence of warfarin or aspirin in patients with chronic atrial fibrillation in general practice: do the appropriate patients receive stroke prophylaxis? J Thromb Haemost. 2008; 6:1500-6.

51. Ogbonna KC, Jeffery SM. Risk versus benefit of non-vitamin K dependent anticoagulants compared to warfarin for the management of atrial fibrillation in the elderly. Drugs Aging. 2013;30:513-25.

52. Di Biase L, Burkhardt JD, Mohanty P, Sanchez J, Mohanty S, Horton R, et al. Left atrial appendage: an underrecognized trigger site of atrial fibrillation. Circulation. 2010;122:109-18.

53. St Jude Medical Investor Conference, 2012, Sources: Health Research Inc (Menands, NY), Management Research Group Inc (Portland, Maine), Miyasaka Y, Barnes ME, Gersh BJ, Cha SS, Bailey KR, Abhayaratna WP, et al. Secular trends in incidence of atrial fibrillation in Olmsted County, Minnesota, 1980 to 2000, and implications on the projections for future prevalence. Circulation. 2006;114:119-25. 
54. Cox JL. The longstanding, persistent confusion surrounding surgery for atrial fibrillation. J Thorac Cardiovasc Surg. 2010;139:1374-86.

55. Gillinov AM, Saltman AE. Ablation of atrial fibrillation with concomitant cardiac surgery. Semin Thorac Cardiovasc Surg. 2007;19:25-32.

56. Gammie JS, Haddad M, Milford-Beland S, Welke KF, Ferguson TBJ, O'Brien SM, et al. Atrial fibrillation correction surgery: lessons from the Society of Thoracic Surgeons National Cardiac Database. Ann Thorac Surg. 2008;85: 909-14.

57. Ad N, Suri RM, Gammie JS, Sheng S, O'Brien SM, Henry L. Surgical ablation of atrial fibrillation trends and outcomes in North America. $J$ Thorac Cardiovasc Surg. 2012;144:1051-60.

58. Kong MH, Lopes RD, Piccini JP, Hasselblad V, Bahnson TD, Al-Khatib SM. Surgical maze procedure as a treatment for atrial fibrillation: a meta-analysis of randomized controlled trials. Cardiovasc Ther. 2010;28:311-26.

59. Forlani S, De Paulis R, Guerrieri Wolf L, Greco R, Polisca P, Moscarelli M, et al. Conversion to sinus rhythm by ablation improves quality of life in patients submitted to mitral valve surgery. Ann Thorac Surg. 2006;81:863-7.

60. Ngaage DL, Schaff HV, Mullany CJ, Barnes S, Dearani JA, Daly RC, et al. Influence of preoperative atrial fibrillation on late results of mitral repair: is concomitant ablation justified? Ann Thorac Surg. 2007;84:434-42; discussion 442-3.

61. Fukunaga S, Hori H, Ueda T, Takagi K, Tayama E, Aoyagi S. Effect of surgery for atrial fibrillation associated with mitral valve disease. Ann Thorac Surg. 2008;86: 1212-7.

62. Itoh A, Kobayashi J, Bando K, Niwaya K, Tagusari O, Nakajima H, et al. The impact of mitral valve surgery combined with maze procedure. Eur J Cardiothorac Surg. 2006;29:1030-5.

63. Kim HK, Kim YJ, Kim KI, Jo SH, Kim KB, Ahn H, et al. Impact of the maze operation combined with left-sided valve surgery on the change in tricuspid regurgitation over time. Circulation. 2005;112:I14-9.
64. Stulak JM, Schaff HV, Dearani JA, Orszulak TA, Daly RC, Sundt TM III Restoration of sinus rhythm by the maze procedure halts progression of tricuspid regurgitation after mitral surgery. Ann Thorac Surg. 2008;86:40-4; discussion 44-5.

65. Louagie Y, Buche M, Eucher P, Schoevaerdts JC, Gerard M, Jamart J, et al Improved patient survival with concomitant Cox maze III procedure compared with heart surgery alone. Ann Thorac Surg. 2009;87:440-6.

66. Lee R, McCarthy PM, Wang EC, Vaduganathan M, Kruse J, Malaisrie SC, et al Midterm survival in patients treated for atrial fibrillation: a propensity-matched comparison to patients without a history of atrial fibrillation. J Thorac Cardiovasc Surg. 2012;143:1341-51; discussion 1350-1.

67. Ad N, Henry L, Hunt S, Holmes SD. Do we increase the operative risk by adding the Cox Maze III procedure to aortic valve replacement and coronary artery bypass surgery? J Thorac Cardiovasc Surg. 2012;143:936-44.

68. Creswell LL, Schuessler RB, Rosenbloom M, Cox JL. Hazards of postoperative atrial arrhythmias. Ann Thorac Surg. 1993;56:539-49.

69. Almassi GH, Schowalter T, Nicolosi AC, Aggarwal A, Moritz TE, Henderson WG, et al. Atrial fibrillation after cardiac surgery: a major morbid event? Ann Surg. 1997;226:501-11; discussion 511-3.

70. Cox JL. A perspective of postoperative atrial fibrillation in cardiac operations. Ann Thorac Surg. 1993;56:405-9.

71. Wang G, Tong X, George MG. Atrial fibrillation associated costs for stroke hospitalizations of Medicare beneficiaries in the stroke belt of the United States. J Afib. 2013;5:7-11.

72. Healey JS, Connolly SJ, Gold MR, Israel CW, Van Gelder IC, Capucci A, et al Subclinical atrial fibrillation and the risk of stroke. $N$ Engl J Med. 2012;366: 120-9.

73. Johnson WD, Ganjoo AK, Stone CD, Srivyas RC, Howard M. The left atrial appendage: our most lethal human attachment! Surgical implications. Eur J Cardiothorac Surg. 2000;17:718-22. 


\section{Further Reading}

Ad N, Cox JL. Stroke prevention as an indication for the Maze procedure in the treatment of atrial fibrillation. Semin Thorac Cardiovasc Surg. 2000;12:56-62.

Ad N, Pirovic EA, Kim YD, Suyderhoud JP, DeGroot KW, Lou HC, et al. Observations on the perioperative management of patients undergoing the maze procedure. Semin Thorac Cardiovasc Surg. 2000;12:63-7.

Ad N, Suyderhoud JP, Kim YD, Makary MA, DeGroot KW, Lue HC, et al. Benefits of prophylactic continuous infusion of furosemide after the maze procedure for atrial fibrillation. J Thorac Cardiovasc Surg. 2002;123:232-6.

Alberts MJ, Eikelboom JW, Hankey GJ. Antithrombotic therapy for stroke prevention in non-valvular atrial fibrillation. Lancet Neurol. 2012;11:1066-81.

Amin A. Oral anticoagulation to reduce risk of stroke in patients with atrial fibrillation: current and future therapies. Clin Interv Aging. 2013;8:75-84.

Aschenberg W, Schluter M, Kremer P, Schroder E, Siglow V, Bleifeld W. Transesophageal two-dimensional echocardiography for the detection of left atrial appendage thrombus. J Am Coll Cardiol. 1986;7:163-6.

Ball J, Carrington MJ, McMurray JJ, Stewart S. Atrial fibrillation: profile and burden of an evolving epidemic in the 21 st century [epub ahead of print]. Int J Cardiol 2013 Feb 1. doi: 10.1016/j.ijcard.2012.12.093.

Benussi S, Mazzone P, Maccabelli G, Vergara P, Grimaldi A, Pozzoli A, et al. Thoracoscopic appendage exclusion with an AtriClip device as a solo treatment for focal atrial tachycardia. Circulation. 2011;123:1575-8.

Blackshear JL, Odell JA. Appendage obliteration to reduce stroke in cardiac surgical patients with atrial fibrillation. Ann Thorac Surg. 1996;61:755-9.

Block PC, Burstein S, Casale PN, Kramer PH, Teirstein P, Williams DO, et al. Percutaneous left atrial appendage occlusion for patients in atrial fibrillation suboptimal for warfarin therapy: 5-year results of the PLAATO (Percutaneous Left Atrial Appendage Transcatheter Occlusion) study. JACC Cardiovasc Interv. 2009; 2:594-600.

Bungard TJ, Ghali WA, Teo KK, McAlister FA, Tsuyuki RT. Why do patients with atrial fibrillation not receive warfarin? Arch Intern Med. 2000;160:41-6.

Collins LJ, Silverman DI, Douglas PS, Manning WJ. Cardioversion of nonrheumatic atrial fibrillation: reduced thromboembolic complications with 4 weeks of precardioversion anticoagulation are related to atrial thrombus resolution. Circulation. 1995;92:160-3.

Cox JL, Boineau JP, Schuessler RB, Ferguson TBJ, Cain ME, Lindsay BD, et al. Successful surgical treatment of atrial fibrillation: review and clinical update. JAMA. 1991;266:1976-80.

Cox JL. The maze III procedure for treatment of atrial fibrillation. In: Sabiston DC, ed. Atlas of Cardiothoracic Surgery. Philadelphia, PA: WB Saunders; 1995. 460-75.

Cox JL. The surgical treatment of atrial fibrillation. IV. Surgical technique. J Thorac Cardiovasc Surg. 1991;101:584-92.

Damiano RJ Jr, Gaynor SL, Bailey M, Prasad S, Cox JL, Boineau JP, et al. The long-term outcome of patients with coronary disease and atrial fibrillation undergoing the Cox maze procedure. J Thorac Cardiovasc Surg. 2003;126: 2016-21.

Edgerton JR, Edgerton ZJ, Weaver T, Reed K, Prince S, Herbert MA, et al. Minimally invasive pulmonary vein isolation and partial autonomic denervation for surgical treatment of atrial fibrillation. Ann Thorac Surg. 2008;86:35-8; discussion 39.

Erdei T, Denes M, Kardos A, Foldesi C, Temesvari A, Lengyel M. Left atrial and left atrial appendage function in paroxysmal atrial fibrillation. Acta Physiol Hung. 2011;98:137-46.

Fatkin D, Feneley MP. Patterns of Doppler-measured blood flow velocity in the normal and fibrillating human left atrial appendage. Am Heart J. 1996;132: 995-1003.

Fatkin D, Kelly RP, Feneley MP. Relations between left atrial appendage blood flow velocity, spontaneous echocardiographic contrast and thromboembolic risk in vivo. J Am Coll Cardiol. 1994;23:961-9.

Flegel KM, Shipley MJ, Rose G. Risk of stroke in non-rheumatic atrial fibrillation. Lancet. 1987;1:526-9.

Flegel KM. When atrial fibrillation occurs with pulmonary embolism, is it the chicken or the egg? Can Med Assoc J. 1999;160:1181-2.

Garcia-Fernandez MA, Perez-David E, Quiles J, Peralta J, Garcia-Rojas I, Bermejo J, et al. Role of left atrial appendage obliteration in stroke reduction in patients with mitral valve prosthesis: a transesophageal echocardiographic study. J Am Coll Cardiol. 2003;42:1253-8.

Garcia-Fernandez MA, Torrecilla EG, San Roman D, Azevedo J, Bueno H, Moreno MM, et al. Left atrial appendage Doppler flow patterns: implications on thrombus formation. Am Heart J. 1992;124:955-61.

Gillinov AM, Pettersson G, Cosgrove DM. Stapled excision of the left atrial appendage. J Thorac Cardiovasc Surg. 2005;129:679-80.
Halperin JL, Hart RG. Atrial fibrillation and stroke: new ideas, persisting dilemmas. Stroke. 1988; 19:937-41.

Hylek EM. Anticoagulation therapy for atrial fibrillation. Semin Thromb Hemost. 2013;39:147-52.

Independent survey conducted at the 91st AATS Annual Meeting, Philadelphia, PA, May 2011 (unpublished data).

Jue J, Winslow T, Fazio G, Redberg RF, Foster E, Schiller NB. Pulsed Doppler characterization of left atrial appendage flow. J Am Soc Echocardiogr. 1993;6: 237-44.

Kagawa K, Arakawa M, Miwa H, Noda T, Nishigaki K, Ito Y, et al. [Left atrial function during left ventricular diastole evaluated by left atrial angiography and left ventriculography]. J Cardiol. 1994;24:317-25.

Kanderian AS, Gillinov AM, Pettersson GB, Blackstone E, Klein AL. Success of surgical left atrial appendage closure: assessment by transesophageal echocardiography. J Am Coll Cardiol. 2008;52:924-9.

Kim KB, Lee CH, Kim CH, Cha YJ. Effect of the Cox maze procedure on the secretion of atrial natriuretic peptide. J Thorac Cardiovasc Surg. 1998;115: 139-46; discussion 146.

Krahn AD, Manfreda J, Tate RB, Mathewson FA, Cuddy TE. The natural history of atrial fibrillation: incidence, risk factors, and prognosis in the Manitoba Follow-Up study. Am J Med. 1995;98:476-84.

La Meir M, Gelsomino S, Luca F, Pison L, Colella A, Lorusso R, et al. Minimal invasive surgery for atrial fibrillation: an updated review. Europace. 2013;15:170-82.

Lee RJ, Bartus K, Yakubov SJ. Catheter-based left atrial appendage (LAA) ligation for the prevention of embolic events arising from the LAA: initial experience in a canine model. Circ Cardiovasc Interv. 2010;3:224-9.

Levy S, Maarek M, Coumel P, Guize L, Lekieffre J, Medvedowsky JL, et al. Characterization of different subsets of atrial fibrillation in general practice in France: the ALFA study. The College of French Cardiologists. Circulation. 1999; 99:3028-35.

Li YH, Lai LP, Shyu KG, Hwang JJ, Kuan P, Lien WP. Clinical implications of left atrial appendage flow patterns in nonrheumatic atrial fibrillation. Chest. 1994; 105:748-52.

Madden JL. Resection of the left auricular appendix: a prophylaxis for recurrent arterial emboli. JAMA. 1949;140:769-72.

Mantha S, Pianka AM, Tsapatsaris N. Determinants of intracranial hemorrhage incidence in patients on oral anticoagulation followed at the Lahey clinic. $J$ Thromb Thrombol. 2011;32:334-42.

Miyasaka Y, Barnes ME, Gersh BJ, Cha SS, Bailey KR, Abhayaratna WP, et al. Secular trends in incidence of atrial fibrillation in Olmsted County, Minnesota, 1980 to 2000, and implications on the projections for future prevalence. Circulation. 2006;114:119-25.

Mohr JP, Albers GW, Amarenco P, Babikian VL, Biller J, Brey RL, et al. American Heart Association Prevention Conference. IV. Prevention and Rehabilitation of Stroke. Etiology of stroke. Stroke. 1997;28:1501-6.

Mugge A, Kuhn H, Nikutta P, Grote J, Lopez JA, Daniel WG. Assessment of left atrial appendage function by biplane transesophageal echocardiography in patients with nonrheumatic atrial fibrillation: identification of a subgroup of patients at increased embolic risk. J Am Coll Cardiol. 1994;23:599-607.

National Stoke Association website. Available from www.stroke.org. Updated. Accessed June 2013.

Omari BO, Nelson RJ, Robertson JM. Effect of right atrial appendectomy on the release of atrial natriuretic hormone. J Thorac Cardiovasc Surg. 1991;102:272-9.

Onalan O, Crystal E. Left atrial appendage exclusion for stroke prevention in patients with nonrheumatic atrial fibrillation. Stroke. 2007;38:624-30.

Ostermayer SH, Reisman M, Kramer PH, Matthews RV, Gray WA, Block PC, et al. Percutaneous left atrial appendage transcatheter occlusion (PLAATO system) to prevent stroke in high-risk patients with non-rheumatic atrial fibrillation: results from the international multi-center feasibility trials. J Am Coll Cardiol. 2005;46:9-14.

Park HC, Shin J, Ban JE, Choi JI, Park SW, Kim YH. Left atrial appendage: morphology and function in patients with paroxysmal and persistent atrial fibrillation. Int J Cardiovasc Imaging. 2013;29:935-44.

Risk factors for stroke and efficacy of antithrombotic therapy in atrial fibrillation: analysis of pooled data from five randomized controlled trials. Arch Intern Med. 1994;154:1449-57.

Singh SM, Dukkipati SR, d'Avila A, Doshi SK, Reddy VY. Percutaneous left atrial appendage closure with an epicardial suture ligation approach: a prospective randomized pre-clinical feasibility study. Heart Rhythm. 2010;7:370-6.

Slater AD, Tatooles AJ, Coffey A, Pappas PS, Bresticker M, Greason K, et al. Prospective clinical study of a novel left atrial appendage occlusion device. Ann Thorac Surg. 2012;93:2035-8; discussion 2038. 
Stefanadis C, Dernellis J, Toutouzas P. Evaluation of the left atrial performance using acoustic quantification. Echocardiography. 1999;16:117-25.

Stroke Statistics. The Internet Stroke Center website. Available from www. strokecenter.org. Updated 2013. Accessed June 2013.

The Stroke Prevention in Atrial Fibrillation Investigators Committee on Echocardiography. Transesophageal echocardiographic correlates of thromboembolism in high-risk patients with nonvalvular atrial fibrillation. Ann Intern Med. 1998;128:639-47.

Visser CA. Echocardiographic evaluation of the left atrial appendage; only a prerogative of transoesophageal echocardiography? Eur J Echocardiogr. 2002; $3: 3-5$.
Wang W, Li H, Tam MD, Zhou D, Wang DX, Spain J. The Amplatzer vascular plug: a review of the device and its clinical applications. Cardiovasc Intervent Radiol. 2012;35:725-40.

Wolf PA, Abbott RD, Kannel WB. Atrial fibrillation as an independent risk factor for stroke: the Framingham study. Stroke. 1991;22:983-8.

Yamada H. Report of the American College of Cardiology (ACC) Scientific Sessions 2013, San Francisco-highlighting late-breaking trials. Circ J. 2013;77:1139-45. Yoshihara F, Nishikimi T, Kosakai Y, Isobe F, Matsuoka H, Takishita S, et al. Atrial natriuretic peptide secretion and body fluid balance after bilateral atrial appendectomy by the maze procedure. J Thorac Cardiovasc Surg. 1998;116: 213-9. 